\title{
Asparagine degradation in Rhizobium etli
}

\author{
Alejandra Huerta-Zepeda, Socorro Durán, Gisela Du Pont \\ and Jorge Calderón
}

Author for correspondence: Jorge Calderón. Tel: +5262238 80. Fax: +525500048 .

Departamento de Biotecnología, Instituto de Investigaciones Biomédicas, Universidad Nacional Autónoma de México, Mexico DF 04510

\begin{abstract}
The degradation of asparagine by Rhizobium etli involves asparaginase and aspartate ammonia-lyase (L-aspartase). The two enzymes were shown to be positively regulated by asparagine and negatively regulated by the carbon source. Asparaginase activity was not regulated by oxygen concentration or by nitrogen catabolite repression. Induction of both enzymes by asparagine enables $R$. et/ $i$ to utilize asparagine as carbon source. Asparaginase may also be involved in maintaining the optimal balance between asparagine and aspartate. Aspartase was not involved in the utilization of aspartate or glutamate as carbon source. The presence of high levels of the two enzymes in $R$. etli bacteroids suggests that they may have a role in symbiosis between $R$. etli and Phaseolus vulgaris.
\end{abstract}

Keywords: Rbizobium etli, asparaginase, aspartase, catabolism, symbiosis

\section{INTRODUCTION}

In some organisms, L-asparagine can be utilized as sole carbon and nitrogen source through the action of two enzymes (Sun \& Setlow, 1991). The first enzyme, asparaginase (EC 3.5.1.1), catalyses the hydrolysis of $\mathrm{L}^{-}$ asparagine to L-aspartate and ammonium. The second enzyme, aspartase ammonia-lyase (L-aspartase; EC 4.3.1.1), catalyses the reversible deamination of $\mathbf{L}_{-}$ aspartate to yield fumarate and ammonium.

Asparaginase activity has been studied in Escherichia coli and other Gram-negative bacteria such as Salmonella enterica (Jennings et al., 1993), Erwinia chrysantbemi (Gilbert et al., 1986) and Vibrio proteus (Sinha et al., 1991), and in Gram-positive bacteria such as Bacillus subtilis (Sun \& Setlow, 1991) and Stapbylococcus aureus (Sobis \& Mikucki, 1991 ; Rózalska \& Mikucki, 1992). E. coli contains two Lasparaginase isozymes. L-Asparaginase I has a low affinity for asparagine, it is cytoplasmic and is thought to be constitutively produced (Jerlström et al., 1989; Willis \& Woolfolk, 1974); L-asparaginase II is a high-affinity enzyme secreted to the periplasm, and its expression is positively regulated by the AMP receptor protein and by anaerobiosis via the product of the fnr gene (Cedar \& Schwartz, 1967; Chesney, 1983; Ho et al., 1970; Jerlström et al., 1987; Russell \& Yamasaki, 1978; Jennings \& Beachman, 1993).

In $S$. enterica, an organism closely related to $E$. coli, Lasparaginase II is regulated by glucose levels in the medium, via the catabolite repressor protein, and by anaerobiosis. However, the anaerobic regulation of this gene does not act via the FNR protein, contrasting with the case in E. coli (Jennings et al., 1993). B. subtilis Lasparaginase and $L$-aspartase are encoded by the ans operon, which is subject to strong repression by a good nitrogen source, such as ammonium, and is also induced by asparagine and aspartate (Sun \& Setlow, 1991; Atkinson \& Fisher, 1991; Iijima et al., 1977).

L-Aspartase activity has been studied in several bacteria, such as E. coli, B. subtilis (Sun \& Setlow, 1991), Pseudomonas fluorescens (Tokushige, 1985; Miyamoto \& Katsuki, 1992) and Serratia marcescens (Takagi \& Kisumi, 1985). E. coli aspartase is activated by divalent ions (Rudolph \& Fromm, 1971; Karsten \& Viola, 1991) and regulated by catabolite repression and by anaerobiosis via the product of the fnr gene (Nishimura \& Kisumi, 1984; Jerlström et al., 1987).

Bacteria of the genus Rbizobium establish intracellular symbiosis with legumes in which the bacteroids fix atmospheric nitrogen and export ammonium to plant tissues. Carbon compounds produced by the plant are metabolized by the bacteria to supply the energy and reductant needed for nitrogen fixation. Identification and analysis of the bacterial and plant enzymes that are active in the nodule are important to understand the metabolic pathways used by both partners during symbiosis.

Kahn et al. (1985) proposed that the carbon supplied to bacteroids includes amino acids. Rastogi \& Watson (1991) found that a Rhizobium meliloti mutant, unable to grow on aspartate as carbon source due to a deficiency of a novel atypical aspartate aminotransferase activity, does not fix 
nitrogen, implying that aspartate is an essential substrate for bacteroids in the nodule (Watson \& Rastogi, 1993).

Considering the importance that amino acid metabolism may have in the Rbizobium symbiosis, together with the finding that Rhizobium etli does not grow on aspartate but does grow on asparagine as carbon source, and that high asparaginase and aspartase activities have been found in Rhizobium lupini bacteroids (Kretovich et al., 1981), we decided to study the degradation of asparagine in R. etli, a bacterium that establishes symbiosis with Pbaseolus vulgaris (bean) (Segovia et al., 1993).

In this report, we present evidence of an asparaginaseaspartase pathway for the degradation of asparagine in $R$. etli and the regulation of these enzymes. The enzymic activities of asparaginase and aspartase in bacteroids are also reported.

\section{METHODS}

Strains. The Rhizobium etli CFN42 wild-type strain used in this study was previously classified as Rbizobium leguminosarum biovar phaseoli (Segovia et al., 1993).

Growth conditions. Batch cultures of R. etli were grown at $30{ }^{\circ} \mathrm{C}$ with shaking at 200 r.p.m. For growth on minimal medium (MM) (Beringer, 1974), cells previously grown overnight on a rich medium (PY) containing $0.5 \%(\mathrm{w} / \mathrm{v})$ peptone, $0.3 \%(\mathrm{w} / \mathrm{v})$ yeast extract and $7 \mathrm{mM} \mathrm{CaCl}_{2}$ were washed and used as inoculum. The initial $\mathrm{OD}_{540}$ of the medium was adjusted to 0.05 . The nitrogen and carbon sources in $\mathrm{MM}$ were added at $10 \mathrm{mM}$, except for glycerol $(2 \%, \mathrm{v} / \mathrm{v})$. Microaerobic cultures were achieved by flushing a tightly stoppered Erlenmeyer flask containing $250 \mathrm{ml}$ medium with nitrogen for $10 \mathrm{~min}$ and readmitting air to give a $1 \%(\mathrm{v} / \mathrm{v})$ oxygen concentration. Growth was monitored by measurement of the $\mathrm{OD}_{540}$ and by protein determination using the Lowry method.

Determination of asparaginase activity. Cell extracts were prepared by sonicating whole cells in extraction buffer $(100 \mathrm{mM}$ $\mathrm{KH}_{2} \mathrm{PO}_{4}, \mathrm{pH} \mathrm{7.6)}$ with a Soniprep 150 ultrasonic disintegrator; homogenates were centrifuged for $5 \mathrm{~min}$ at 12000 r.p.m. (Beckman JA-20 fixed-angle rotor) at $4{ }^{\circ} \mathrm{C}$. The assay measuring ammonium formation was performed in a $0.25 \mathrm{ml}$ reaction mixture containing $30 \mathrm{mM} \mathrm{KH}_{2} \mathrm{PO}_{4}, \mathrm{pH} 7 \cdot 6,10 \mathrm{mM}$ asparagine and $0.05 \mathrm{ml}$ cell extract. Ammonium formation was measured as described elsewhere (Chaney \& Marbach, 1962; Durán \& Calderón, 1995). The assay measuring the formation of aspartate was performed in a $1 \mathrm{ml}$ reaction mixture containing $30 \mathrm{mM}$ $\mathrm{KH}_{2} \mathrm{PO}_{4}, \mathrm{pH} 7.6,10 \mathrm{mM}$ asparagine and $0.2 \mathrm{ml}$ cell extract. Aspartate was determined with a System Gold Liquid Chromatographic system from Beckman and a Gilson Fluorometer model 121 after coupling with $o$-phthalaldehyde (Calderón et al., 1985).

Determination of aspartase activity. Cell extracts were prepared by sonicating whole cells in extraction buffer $(50 \mathrm{mM}$ $\mathrm{KH}_{2} \mathrm{PO}_{4}, 100 \mathrm{mM} \mathrm{KCl}, 1 \mathrm{mM}$ EDTA, $5 \mathrm{mM}$ 2-mercaptoethanol, $\mathrm{pH}$ 8) as described above. Assays for fumarate formation were carried out spectrophotometrically (Beckman DU 640 spectrophotometer) at $240 \mathrm{~nm}$, the reaction mixture in a total volume of $1 \mathrm{ml}$ containing $100 \mathrm{mM}$ Tris/ $\mathrm{HCl}, \mathrm{pH} 8 \cdot 8$, $100 \mathrm{mM}$ aspartate, $2 \mathrm{mM} \mathrm{MgCl}$ and $0.025 \mathrm{ml}$ cell extract (Tokushige, 1985). In the stoichiometry of aspartase, the assay mixture contained $30 \mathrm{mM} \mathrm{KH}_{2} \mathrm{PO}_{4}, \mathrm{pH} 8.8$, instead of $100 \mathrm{mM}$ Tris $/ \mathrm{HCl}, \mathrm{pH} 8 \cdot 8$, since Tris/ $\mathrm{HCl}$ interfered with the determination of ammonium, although activity measured with phosphate buffer was $45 \%$ lower than with Tris/ $\mathrm{HCl}$ buffer.
The assay for ammonium formation was performed in a $0.25 \mathrm{ml}$

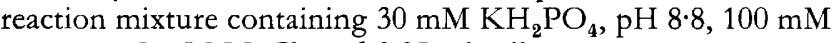
aspartate, $2 \mathrm{mM} \mathrm{MgCl}_{2}$ and $0.05 \mathrm{ml}$ cell extract.

Determination of aspartate aminotransferase activity. Cell extracts were prepared in extraction buffer $\left(100 \mathrm{mM} \mathrm{KH}_{2} \mathrm{PO}_{4}\right.$, $\mathrm{pH} 7 \cdot 6)$ as described above. The homogenates were centrifuged for $2 \mathrm{~min}$ at room temperature in a microcentrifuge and dialysed overnight against extraction buffer plus $0.01 \mathrm{mM}$ pyridoxal 5phosphate at $4{ }^{\circ} \mathrm{C}$. Oxaloacetate formation was determined spectrophotometrically as described elsewhere (Rej \& Hørder, 1987).

Determination of fumarase activity. Cell extracts were prepared in extraction buffer $\left(100 \mathrm{mM} \mathrm{KH}_{2} \mathrm{PO}_{4}, \mathrm{pH} 7.6\right)$ as described above and the homogenates were centrifuged for $2 \mathrm{~min}$ at room temperature in a microcentrifuge. Fumarate formation was determined spectrophotometrically as described elsewhere (Stitt, 1984).

Determination of glutamine synthetase activity. Glutamine synthetase activity was assayed with cell extracts prepared by sonicating the cells in $10 \mathrm{mM}$ imidazole hydrochloride and $0.5 \mathrm{mM}$ EDTA ( $\mathrm{pH} 7 \cdot 0$ ). It was measured by its synthetase activity as described by Bender et al. (1977).

Bacteroid isolation. Bacteroids from root nodules of $P$. vulgaris were isolated by utilizing self-generating Percoll gradients as described by Reibach $e$ t al. (1981). A crude extract was prepared by gently crushing 6 g nodules with a mortar and pestle in $15 \mathrm{ml}$ grinding buffer (150 mM NaCl and $\left.50 \mathrm{mM} \mathrm{KH}_{2} \mathrm{PO}_{4}, \mathrm{pH} \mathrm{7 \cdot 6}\right)$. The crude homogenate was filtered through four layers of cheesecloth and the residue was washed with additional grinding buffer. The filtered crude extract was centrifuged for $5 \mathrm{~min}$ at 3000 r.p.m. (Beckman Instrument JA-20 fixed-angle rotor) at $4{ }^{\circ} \mathrm{C}$, the supernatant was centrifuged again for $15 \mathrm{~min}$ at 15000 r.p.m. and the pellet was resuspended in $2 \mathrm{ml}$ grinding buffer. A $50 \mathrm{ml}$ polycarbonate centrifuge tube was filled with $24.5 \mathrm{ml}$ Percoll concentrate, $3.5 \mathrm{ml} 500 \mathrm{mM} \mathrm{KH}_{2} \mathrm{PO}_{4}$ plus $1.5 \mathrm{M}$ $\mathrm{NaCl}, \mathrm{pH} 7 \cdot 6$, and $7 \mathrm{ml} \mathrm{H}_{2} \mathrm{O}$, giving a final concentration of $70 \%$ Percoll. One millilitre of extract was layered on the top of the gradient. The tube was centrifuged for $50 \mathrm{~min}$ at 20000 r.p.m. The bacteroids were collected with a Pasteur pipette. Percoll was removed by diluting the fraction $1: 10$ with $150 \mathrm{mM} \mathrm{NaCl}$ and $50 \mathrm{mM} \mathrm{KH} \mathrm{PO}_{4}, \mathrm{pH} 7 \cdot 6$, and centrifuging for $20 \mathrm{~min}$ at 15000 r.p.m. The pellet was resuspended in $2 \mathrm{ml}$ extraction buffer.

\section{RESULTS AND DISCUSSION}

\section{Growth of $R$. etli on aspartate and asparagine as nitrogen and carbon source}

R. etli grew very poorly on aspartate as nitrogen and carbon source, whereas on aspartate as nitrogen source and succinate as carbon source it grew as well as on ammonium plus succinate (Fig. 1). In contrast, on glutamate as nitrogen and carbon source, R. etli grew at half the rate observed with glutamate plus succinate. On asparagine as nitrogen and carbon source, $R$. etli grew almost as well as on asparagine plus succinate (Fig. 1). These results indicate that $R$. etli utilized aspartate, glutamate and asparagine as nitrogen sources, that aspartate is a poor carbon source and that asparagine is a good carbon source, in spite of the fact that in order to be utilized as carbon source, asparagine must first be degraded to aspartate. 


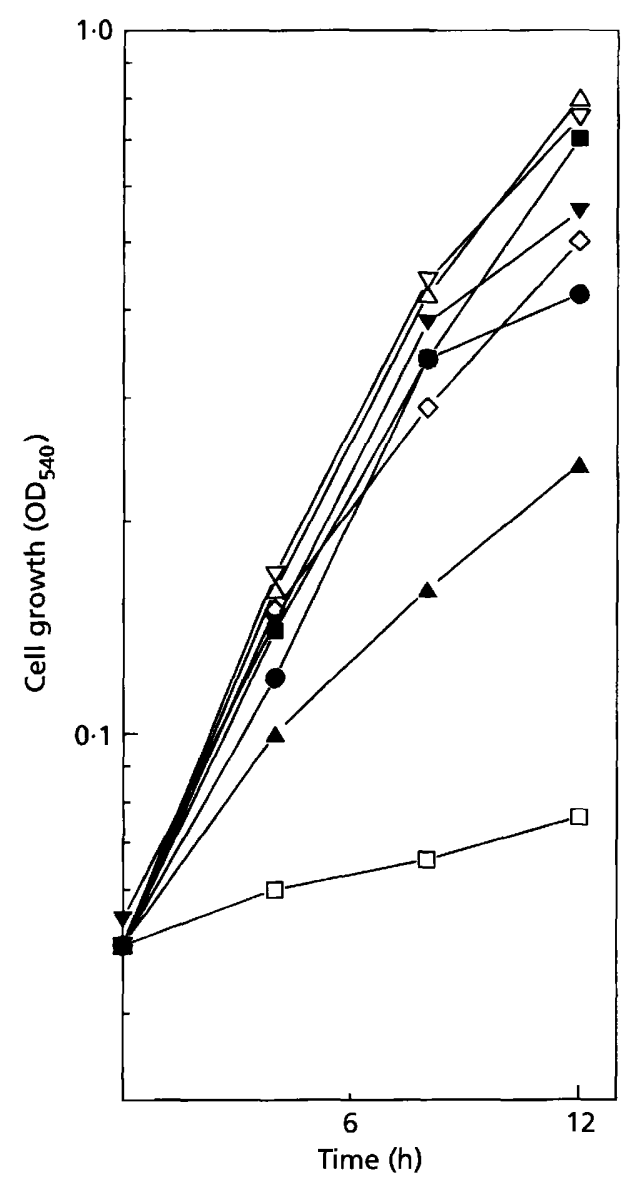

Fig. 1. Growth curves of $R$. etli from cultures grown on: ammonium plus succinate $(\nabla)$, peptone-yeast extract $(\triangle)$, asparagine plus succinate $(\nabla)$, asparagine $(\Theta)$, aspartate plus succinate $(\square)$, aspartate $(\square)$, glutamate plus succinate $(\diamond)$ and glutamate ( $\mathbf{\Delta})$.

\section{Asparaginase}

The assay conditions for measurement of asparaginase activity were optimized. It was shown that the amounts of aspartate $(1.05 \mu \mathrm{mol})$ and ammonium $(1.16 \mu \mathrm{mol})$ formed were similar.

Asparaginase activity was highest when $R$. etli was grown on asparagine as nitrogen and carbon source, and this activity decreased when $R$. etli was grown on asparagine plus another carbon source such as glycerol, glucose or succinate (Table 1). Asparaginase activity was similar when $R$. etti was grown on asparagine plus succinate in the absence or presence of ammonium, and low when bacteria were grown on a good inorganic nitrogen source such as ammonium or a poor nitrogen source such as nitrate. Asparaginase activity was low in cells grown on aspartate with or without succinate such as in ammonium plus succinate. When $R$. etli was grown on other amino acids such as glutamine, and glutamate with or without succinate, or on a rich PY medium, asparaginase activity was low (Table 1). When $R$. etli was grown on ammonium plus succinate, asparaginase activity was similar during the different growth stages (data not shown). The amount of oxygen dissolved in the growth medium was found to be irrelevant to the asparaginase activity (Table 1).

This shows that asparaginase was: (a) positively regulated by its substrate asparagine as in B. subtilis (Sun \& Setlow, 1991) and $V$. proteus (Sinha et al., 1991), and (b) negatively regulated by the carbon source as shown by the reduction in the asparaginase activity when a carbon source such as glycerol, glucose or succinate was present in the growth medium in addition to asparagine. Similar findings have been reported for E. coli (Jennings \& Beachman, 1993), S. enterica (Jennings et al., 1993) and Staph. aureus (Rózalska \& Mikucki, 1992).

R. etli asparaginase was not regulated by: (a) the amount of oxygen dissolved in the growth medium, in contrast to other bacteria such as E. coli (Jennings \& Beachman, 1993), S. enterica (Jennings et al., 1993) and V. proteus (Sinha et al., 1991); (b) nitrogen catabolite repression, as shown by the inability of ammonium to reduce asparaginase activity and the low activity found when $R$. etli was grown on a poor nitrogen source (Table 1), in contrast with data for B. subtilis (Sun \& Setlow, 1991), Bacillus licheniformis (Golden \& Betnloht, 1985) and Saccharomyces cerevisiae (Roon et al., 1982). Our results suggest that R. etli asparaginase plays a catabolic role in the degradation of asparagine to carbon skeletons when this amino acid is present in the growth medium and may also play a role in maintaining the balance between asparagine and aspartate since some activity is present when $R$. etli is grown in medium without asparagine.

\section{Aspartase}

We found that magnesium was necessary in the assay mixture for optimal R. etli aspartase activity, giving a threefold stimulation. In the complete assay, the amounts of ammonium $(1.14 \mu \mathrm{mol})$ and fumarate $(1.07 \mu \mathrm{mol})$ formed were similar.

The influence of nutritional conditions on aspartase activity was examined. The highest aspartase activity was found when $R$. etli was grown on asparagine as nitrogen and carbon source, suggesting positive regulation as in $B$. subtilis (Sun \& Setlow, 1991). This activity decreased when $R$. etli was grown on asparagine plus another carbon source such as glycerol, glucose or succinate (Table 1), suggesting negative regulation as in E. coli (Nishimura \& Kisumi, 1984). Aspartase activity decreased when $R$. etli was grown on asparagine plus succinate in the presence of ammonium, suggesting repression by ammonium. Aspartase activity was low when bacteria were grown on a good inorganic nitrogen source, such as ammonium, or on a poor nitrogen source, such as nitrate. Aspartase activity was also low in cells grown on aspartate with or without succinate. When R. etli was grown on other amino acids such as glutamine, and glutamate with or without succinate, or on a rich PY medium, aspartase activity was low (Table 1). The amount of oxygen dissolved in the growth medium was found to be 
Table 1. Asparaginase and aspartase activities of $R$. etli grown under different conditions

The activities were measured after $18 \mathrm{~h}$ growth. The numbers in parentheses represent the standard deviations.

\begin{tabular}{|c|c|c|c|c|}
\hline \multirow[t]{2}{*}{ Nitrogen/carbon source } & \multicolumn{2}{|c|}{ Asparaginase } & \multicolumn{2}{|l|}{ Aspartase } \\
\hline & $\begin{array}{l}\text { Specific activity [ } \mathrm{nmol} \\
\text { ammonium } \mathrm{min}^{-1}(\mathrm{mg} \\
\left.\text { protein })^{-1}\right]\end{array}$ & $\begin{array}{c}\text { Relative } \\
\text { activity (\%) }\end{array}$ & $\begin{array}{c}\text { Specific activity } \\
{\left[\mathrm{nmol} \text { fumarate } \mathrm{min}^{-1}\right.} \\
\left.(\mathrm{mg} \text { protein })^{-1}\right]\end{array}$ & $\begin{array}{c}\text { Relative } \\
\text { activity (\%) }\end{array}$ \\
\hline Asparagine & $34 \cdot 6(6)$ & 100 & $390 \cdot 3(50)$ & 100 \\
\hline Asparagine/glycerol & $14 \cdot 0(2)$ & $40 \cdot 5$ & $32 \cdot 3(6)$ & $8 \cdot 7$ \\
\hline Asparagine/glucose & $12 \cdot 2(2)$ & $35 \cdot 3$ & $26 \cdot 8(4)$ & 6.9 \\
\hline Asparagine/succinate & $16 \cdot 0(3)$ & $46 \cdot 2$ & $261 \cdot 0(30)$ & $60 \cdot 4$ \\
\hline Asparagine/ammonium/succinate & $13 \cdot 7(3)$ & $39 \cdot 6$ & $92 \cdot 4(15)$ & $23 \cdot 7$ \\
\hline Ammonium/glycerol & $3 \cdot 7(1)$ & $10 \cdot 7$ & $8 \cdot 4(2)$ & $2 \cdot 15$ \\
\hline Ammonium/glucose & $6 \cdot 0(1)$ & $17 \cdot 3$ & $1.5(1)$ & $0 \cdot 4$ \\
\hline Ammonium/succinate & $4 \cdot 5(1)$ & $13 \cdot 0$ & $16 \cdot 2(3)$ & $4 \cdot 15$ \\
\hline Nitrate/succinate & $5 \cdot 5(1)$ & $15 \cdot 9$ & $10 \cdot 0(2)$ & $2 \cdot 6$ \\
\hline Aspartate/succinate & $4 \cdot 1(1)$ & $11 \cdot 8$ & $8 \cdot 1(2)$ & $2 \cdot 1$ \\
\hline Glutamine/succinate & $2 \cdot 5(1)$ & $7 \cdot 2$ & $12 \cdot 0(2)$ & $3 \cdot 1$ \\
\hline Glutamate/succinate & $3.5(1)$ & $10 \cdot 1$ & $7 \cdot 8(2)$ & $2 \cdot 0$ \\
\hline Aspartate & $4 \cdot 7(1)$ & $13 \cdot 6$ & $30 \cdot 4(7)$ & $7 \cdot 8$ \\
\hline Glutamine & $3.7(1)$ & $10 \cdot 7$ & $12 \cdot 1(2)$ & $3 \cdot 1$ \\
\hline Glutamate & $3 \cdot 4(1)$ & $9 \cdot 8$ & $16 \cdot 3(3)$ & $4 \cdot 2$ \\
\hline Peptone-yeast extract & $2 \cdot 9(1)$ & $8 \cdot 4$ & $3 \cdot 2(1)$ & $0 \cdot 8$ \\
\hline Asparagine/succinate, low $\mathrm{O}_{2}$ & $15 \cdot 3(2)$ & $44 \cdot 2$ & $230 \cdot 5(25)$ & $59 \cdot 1$ \\
\hline Ammonium/succinate, low $\mathrm{O}_{2}$ & $4 \cdot 7(1)$ & $13 \cdot 6$ & $15 \cdot 2(3)$ & $3 \cdot 9$ \\
\hline
\end{tabular}

irrelevant to the aspartase activity (Table 1), in contrast with other bacteria such as E. coli.

\section{Aspartate aminotransferase, fumarase and glutamine synthetase}

The activity of aspartate aminotransferase, an enzyme involved in aspartate catabolism, was determined in R. etli crude extracts. This enzyme catalyses the reversible conversion of aspartate plus 2-oxoglutarate to glutamate plus oxaloacetate. We found that the levels of the enzyme were similar [ $310 \mathrm{nmol} \mathrm{min}^{-1}(\mathrm{mg} \text { protein })^{-1}$ ] when $R$. etli was grown on ammonium plus succinate, PY medium and asparagine or aspartate with or without succinate.

The activity of the Krebs cycle enzyme fumarate hydratase (fumarase), which catalyses the reversible conversion of fumarate to malate, was determined. The levels of this enzyme were similar when $R$. etli was grown on asparagine or aspartate plus succinate $\left[550 \mathrm{nmol} \mathrm{min} \mathrm{m}^{-1}\right.$ (mg protein $)^{-1}$ ]. This activity was slightly lower when R. etli was grown on asparagine or aspartate $\left[390 \mathrm{nmol} \mathrm{min}{ }^{-1}(\mathrm{mg}\right.$ protein $)^{-1}$.

The activity of the ammonium assimilation enzyme glutamine synthetase, which catalyses the synthesis of glutamine from ammonium, ATP and glutamate, was also determined. The level of this enzyme when $R$. etli was grown on asparagine plus succinate was similar to that under conditions of ammonium plus succinate [22 nmol $\left.\min ^{-1}(\mathrm{mg} \text { protein })^{-1}\right]$. Under conditions of aspartate plus succinate, glutamine synthetase activity was threefold higher than with ammonium plus succinate. The levels of this enzyme under conditions of asparagine and aspartate were similar (sevenfold lower than on ammonium plus succinate).

The fact that $R$. etli does not grow on aspartate as nitrogen and carbon source despite containing aspartase is explained by the very low aspartase activity found under these conditions. The poor growth on aspartate is not due to lack of fumarase or glutamine synthetase since these enzyme activities were similar when $\mathrm{R}$. etli was grown on asparagine or aspartate as nitrogen and carbon source. The higher glutamine synthetase activity found when grown on aspartate plus succinate, in comparison with asparagine plus succinate, indicates that aspartate is a poor nitrogen source, since glutamine synthetase is induced under conditions of nitrogen limitation (Bravo \& Mora, 1988). The poor growth on aspartate as nitrogen and carbon source indicates an incapacity of enzymes otherwise capable of degrading aspartate under these conditions, such as aspartate aminotransferase, the enzyme responsible for the growth of $R$. meliloti under the same conditions (Rastogi \& Watson, 1991; Watson \& Rastogi, 1993). The low aspartase activity found on glutamate as nitrogen and carbon source indicates that glutamate must be degraded to carbon skeletons by another enzyme. It is interesting that the physiological role of aspartase is not to enable R. etli to utilize aspartate or glutamate as carbon source. Instead, aspartase is induced by asparagine along with asparaginase to enable $R$. etli to utilize asparagine as carbon source. This contrasts with B. subtilis, where 
aspartase is induced by aspartate and enables $B$. subtilis to grow on aspartate as nitrogen and carbon source (Iijima $e t$ al., 1977; Sun \& Setlow, 1991), and with E. coli, where aspartase participates in two metabolic processes: the regeneration of oxaloacetate as amino acceptor for enabling growth on glutamate, and the formation of fumarate and succinate during anaerobic growth on glucose (Marcus \& Halpern, 1969; Courtright \& Henning, 1970)

\section{Asparaginase and aspartase activities of bacteroids from $R$. etli}

The role of asparagine-degrading enzymes in bacteroids was analysed by isolating $R$. etli bacteroids in a selfgenerating Percoll gradient (Reibach et al., 1981) and assessing the asparagine-degrading enzyme activities. The nodules were harvested $28 \mathrm{~d}$ post-inoculation. The asparaginase activity in bacteroids $\left[38 \mathrm{nmol} \mathrm{min}{ }^{-1}\right.$ (mg protein $)^{-1}$ ] was as high as the activity found when R. etli was grown on asparagine as nitrogen and carbon source (Table 1). The aspartase activity was also high in bacteroids [164 $\mathrm{nmol} \mathrm{min}^{-1}$ (mg protein) ${ }^{-1}$ ].

These observations may indicate roles for these two enzymes in the symbiosis between R. etli and P. vulgaris. The degradation of asparagine by asparaginase and aspartase in bacteroids may also be important in other species of Rbizobium, such as in R. lupini, where levels of these enzymes have been found to be elevated (Kretovich et al., 1981).

\section{ACKNOWLEDGEMENTS}

We are grateful to O. Ladron de Guevara, L. García and P. Padilla for amino acid determinations and to Isabel Pérez Montfort for critical review of the manuscript. This work was supported by DGAPA Grant IN203193 from the Universidad Nacional Autónoma de México and by the Consejo Nacional de Ciencia y Tecnología.

\section{REFERENCES}

Atkinson, M. \& Fisher, S. F. (1991). Identification of genes and gene products whose expression is activated during nitrogen-limited growth in Bacillus subtilis. J Bacteriol 173, 23-27.

Bender, R. A., Janssen, K. S., Resnick, A. D., Blumenberg, M., Foor, F. \& Magasanik, B. (1977). Biochemical parameters of glutamine synthetase from Klebsiella aerogenes. I Bacteriol 129, 1001-1009.

Beringer, J. E. (1974). R factor transfer in Rbizobium leguminosarum. $J$ Gen Microbiol 84, 188-198.

Bravo, A. \& Mora, J. (1988). Ammonium assimilation in Rhizobium phaseoli by the glutamine synthetase-glutamate synthase pathway. J Bacteriol 170, 980-984.

Calderón, J., Morett, E. \& Mora, J. (1985). $\omega$-Amidase pathway in the degradation of glutamine in Neurospora crassa. J Bacteriol 161, 807-809.

Cedar, H. \& Schwartz, J. H. (1967). Localization of two Lasparaginases in anaerobically grown Escherichia coli. J Biol Chem $242,3753-3755$.
Chaney, A. L. \& Marbach, E. P. (1962). Modified reagents for the determination of urea and ammonia. Clin Chem 8, 130-132.

Chesney, R. H. (1983). E. coli L-asparaginase II production in the presence and absence of catabolite activation protein. FEMS Microbiol Lett 17, 161-162.

Courtright, J. B. \& Henning, U. (1970). Malate dehydrogenase mutants of Escherichia coli K-12. J Bacteriol 102, 722-728.

Durán, S. \& Calderón, J. (1995). Role of the glutamine transaminase- $\omega$-amidase pathway and glutaminase in glutamine degradation in Rbizobium etli. Microbiology 141, 589-595.

Gilbert, H. J., Blazek, R., Bullman, H. M. S. \& Minton, N. P. (1986). Cloning and expression of the Erwinia crysanthemi asparaginase gene in Escherichia coli and Erwinia carotovora. J Gen Microbiol 132, 151-160.

Golden, K. J. \& Bernlohr, R. W. (1985). Nitrogen catabolite repression of the $\mathbf{L}$-asparaginase of Bacillus licheniformis. $J$ Bacteriol 164, 938-940.

Ho, P. P. K., Milikin, E. B., Bobbit, J. L., Grinnan, E. L., Burk, P. J., Frank, B. H., Boeck, L. D. \& Squires, R. W. (1970). Crystalline Lasparaginase from Escherichia coli B. I. Purification and chemical characterization. J Biol Chem 245, 3708-3715.

lijima, T., Diesterhaft, M. D. \& Freese, E. (1977). Sodium effect of growth on aspartate and genetic analysis of a Bacillus subtilis mutant with high aspartase activity. $J$ Bacteriol 129, 1440-1447.

Jennings, M. P. \& Beachman, I. R. (1993). Co-dependent positive regulation of the ans $B$ promoter of Escherichia coli by CRP and the FNR protein: a molecular analysis. Mol Microbiol 9, 155-164.

Jennings, M. P., Scott, S. P. \& Beachman, I. R. (1993). Regulation of the asnB gene of Salmonella enterica. Mol Microbiol 9, 165-172.

Jerlström, P. G., Liui, J. \& Beachman, I. R. (1987). Regulation of Eschericbia coli L-asparaginase II and L-aspartase by the fnr gene product. FEMS Microbiol Lett 41, 127-130.

Jerlström, P. G., Bezak, D. A., Jennings, M. P. \& Beachman, I. R. (1989). Structure and expression in Escherichia coli K-12 of the asparaginase I-encoding ans $A$ gene, and its flanking regions. Gene 78, 37-46.

Kahn, M. L., Kraus, J. \& Somerville, J. E. (1985). A model of nutrient exchange in the Rbizobium-legume symbiosis. In Nitrogen Fixation Research Progress, pp. 193-199. Edited by H. Evans, P. Bottomley \& W. E. Newton. New York: M. J. Nijhoff.

Karsten, W. E. \& Viola, R. E. (1991). Kinetics studies of L-aspartase from Escherichia coli: $\mathrm{pH}$-dependent activity changes. Arch Biochem Biopbys 287, 60-67.

Kretovich, V. L., Sidel'nikova, L. I., Ivanushkin, A. G. \& Karayakina, T. I. (1981). Localization of aspartase, asparaginase, and glutaminase in intact bacteroids of Rhizobium lupini. Prikl Biokbim Mikerobiol 20, 445-447.

Marcus, M. \& Halpern, Y. S. (1969). The metabolic pathway of glutamate in Escherichia coli K-12. Biochim Biophys Acta 177, 314-320.

Miyamoto, K. \& Katsuki, H. (1992). Possible physiological roles of aspartase, NAD- and NADP-requiring glutamate dehydrogenase of Pseudomonas fuorescens. J Biocbem 112, 52-56.

Nishimura, N. \& Kisumi, M. (1984), Aspartase-hyperproducing mutants of Eschericbia coli B. Appl Environ Microbiol 48, 1072-1075.

Rastogi, V. K. \& Watson, R. J. (1991). Aspartate aminotransferase activity is required for aspartate catabolism and symbiotic nitrogen fixation in Rhiqobium meliloti. J Bacteriol 173, 2879-2887.

Reibach, P. H., Mask, P. L. \& Streeter, J. G. (1981). A rapid one-step method for the isolation of bacteroids from root nodules of soybean 
plants, utilizing self-generating Percoll gradients. Can J Microbiol 27, 491-495.

Rej, R. \& Hørder, M. (1987). Aspartate aminotransferase. In Methods of Enzymatic Analysis, 3rd edn, vol. 3, pp. 416-444. Edited by H. U. Bergmeyer. Weinheim: VCH.

Roon, R. J., Murdoch, M., Kunze, B. \& Dunlop, P. C. (1982). Derepression of asparaginase II during exponential growth of Saccharomyces cerevisiae on ammonium ion. Arch Biochem Biopbys 219, 101-109.

Rózalska, M. \& Mikucki, J. (1992). Staphylococcal L-asparaginase: catabolic repression of synthesis. Acta Microbiol Pol 41, 145-150.

Rudolph, F. B. \& Fromm, H. J. (1971). The purification and properties of aspartase from Escherichia coli. Arch Biochem Biophys 147, 92-98.

Russell, L. V. \& Yamasaki, H. (1978). The dependence of Escherichia coli asparaginase II formation on cyclic AMP and cyclic AMP receptor protein. Can J Microbiol 24, 629-631.

Segovia, L., Young, P. W. \& Martínez-Romero, E. (1993). Reclassification of American Rhizobium leguminosarum biovar phaseoli type I as Rbizobium etli sp. nov. Int J Syst Bacteriol 43, 374-377.

Sinha, A., Manna, S., Roy, S. K. \& Chakrabarty, S. L. (1991). Induction of L-asparaginase in Vibrio proteus. Indian J Med Res 93, 289-292.
Sobis, M. \& Mikucki, J. (1991). Staphylococcal L-asparaginase: enzyme kinetics. Acta Microbiol Pol 40, 143-152.

Stitt, M. (1984). Fumarase. In Methods of Enzymatic Analysis, 3rd edn, vol. 4, pp. 359-362. Edited by H. U. Bergmeyer. Weinheim: Verlag Chemie.

Sun, D. \& Setlow, P. (1991). Cloning, nucleotide sequence, and expression of the Bacillus subtilis ans operon, which codes for Lasparaginase and L-aspartase. $J$ Bacteriol 173, 3831-3845.

Takagi, T. \& Kisumi, M. (1985). Isolation of a versatile Serratia marcescens mutant as a host and molecular cloning of the aspartase gene. J Bacteriol 161, 1-6.

Tokushige, M. (1985). Aspartate amino-lyase. Methods Envymol 17, 618-627.

Watson, R. J. \& Rastogi, V. K. (1993). Cloning and nucleotide sequencing of Rbizobium meliloti aminotransferase genes: an aspartate aminotransferase required for symbiotic nitrogen fixation is atypical. J Bacteriol 175, 1919-1928.

Willis, R. C. \& Woolfolk, C. A. (1974). Asparagine utilization in Escherichia coli. J Bacteriol 118, 231-241.

Received 25 October 1995; revised 19 December 1995; accepted 22 December 1995. 